[Original]

\title{
Evaluation of Dietary Intake Using Carbon and Nitrogen Isotope Analysis of Human Hair of Chinese Living in Southern Part of China
}

\author{
Noritaka ToKUI ${ }^{1}$, Yoshimi MINARI ${ }^{2}$, Kikue KUSUNOKI ${ }^{2}$, \\ Takesumi Yoshimura $^{1}$, Torao YAMAMOTO ${ }^{3}$ and Masao MinAGAWA ${ }^{4}$ \\ ${ }^{1}$ Department of Clinical Epidemiology, Institute of Ecological Science, University of Occupational and \\ Environmental Health, Japan. Yahatanishi-ku, Kitakyushu 807-8555, Japan \\ ${ }^{2}$ Division of Food and Nutrition, Nakamura Gakuen Junior College. \\ Jounan-ku, Fukuoka 814-0104, Japan \\ ${ }^{3}$ Nakamura Gakuen University. Jounan-ku, Fukuoka 814-0104, Japan \\ ${ }^{4}$ Hokkaido University, Graduate School of Environmental Earth Science. \\ Kita-ku, Sapporo 060-0810, Japan
}

Abstract: We examined dietary intakes among 69 people of three ethnic groups (Yao Chinese, Zhung Chinese and Han Chinese) in the autonomous country of Bama in China where many elderly people have a long life span in 1998. Dietary intake was evaluated using carbon and nitrogen isotope ratios of human hair $\left(\delta^{13} \mathrm{C}, \delta{ }^{15} \mathrm{~N}\right)$ standardized by standard gas. The distributions of $\delta{ }^{13} \mathrm{C}$ in Yao Chinese and Han Chinese were scattered from -21 to $-17 \%$, which were close to that of $\mathrm{C} 4$ plants such as corn and millet. The distribution of $\delta{ }^{13} \mathrm{C}$ in Zhung Chinese was located from -25 to $-22 \%$, which was near that of $\mathrm{C} 3$ plants such as rice, wheat and potato. These values showed a much wider range when compared with $\delta{ }^{13} \mathrm{C}$ in Chinese living in urban areas. On the other hand, $\delta{ }^{15} \mathrm{~N}$ in each group was distributed in the area ranged from 8 to $11 \%$. The result of $\delta{ }^{13} \mathrm{C}$ was consistent with data obtained from a nutritional survey, but that of $\delta{ }^{15} \mathrm{~N}$ was a little higher than expected. The carbon and nitrogen isotope ratios of human hair among three ethnic groups showed characteristic distributions, although the relation between these isotope ratios and longevity is uncertain.

Key words: Chinese, dietary intake, carbon, nitrogen, isotope analysis.

(Received 15 February 2000, accepted 11 July 2000)

\section{Introduction}

Recent isotope studies on the human body have shown that carbon and nitrogen isotope ratios of human hair reflect the food that people consume in daily life $[1,2]$. Carbon and 
nitrogen isotope ratios of organisms are determined by the isotopes of suppliers of organic carbon and nitrogen in the global ecology [3]. Carbon isotope fractionation is associated with three modes of photosynthesis which are classified based on the method of assimilation of carbonic acid gas. The first mode is the $\mathrm{C} 3$ plant which has the Calvin and Benson system, and the second one is called the $\mathrm{C} 4$ plant which has the Hatch and Slack system. The last one is the CAM plants which has crassulasian acid metabolism for photosynthesis. These three kinds of plant have significantly different carbon isotope ratios even though they obtain their initial carbon from the same source, atmospheric carbonic acid gas. In contrast to carbon isotope, nitrogen isotope ratios of plants are mostly controlled by the isotope ratio of their substrates, such as ammonia in soil and water, and atmospheric di-nitrogen for leguminous plants $[4]$.

Additionally, feeding processes of animals modify both carbon and nitrogen isotope ratios of their body tissues. The nitrogen isotope ratio of animals is usually enriched $3.5 \%$ over that of food proteins [5]. The carbon isotope ratio fractionation is likely to be less than that of nitrogen [6]. These findings indicate that such biological processes in plants and humans finally determine the carbon and nitrogen isotope ratios of the human body. In other words, these isotope ratios of the human body reflect dietary habits in humans.

The carbon ratio of human hair has a half-life of 47.5 days which is much longer than that of other organs such as brain, muscle, liver and fat [7]. Besides, human hair lengthens a few centimeters each month. Therefore carbon and nitrogen isotope ratios of human hair are possible indicators of long-term food intake and can distinguish people with different dietary habits.

Previous isotope studies on human hair have been conducted to chiefly target the general population $[1,2]$. This time we had an opportunity to conduct a dietary survey in cooperation with a Chinese researcher in a small autonomous country in China where many people have lived a long life. Consequently, we examined the isotope ratios of carbon and nitrogen of human hair to investigate whether there are distinctive patterns in the isotope ratios among people with a long life span.

\section{Materials and Methods}

\section{Subjects}

We conducted a dietary survey in the autonomous country of Bama in Guangxi which is bordered on the east by Guangdong, on the west by Yunnan and on the south by Vietnam (Fig. 1 ). A national census conducted in China in 1990 reported that there was a population of 230,000, which consisted of 150,000 Zhung Chinese, 35,000 Han Chinese and 33,000 Yao Chinese. The proportion of persons aged over 99 in the population was $29.5 / 100,000$ according to this census. A population census taken in Japan in 1990 reported that this proportion in Okinawa prefecture was 13.3/100,000. In collaboration with Dr. Chen, President 


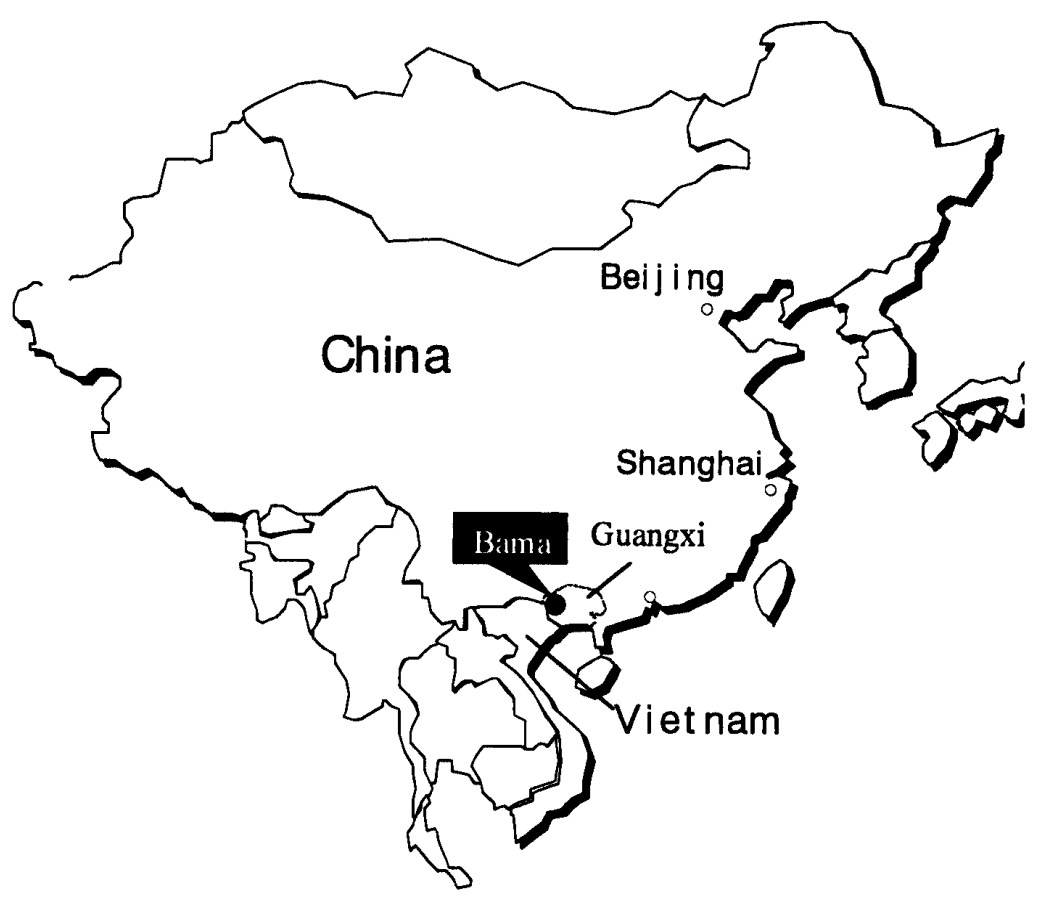

Fig. 1. The autonomous country of Bama.

of Guangxi Longevity Research Center, we visited each of the elderly people and obtained informed consent through interpreters. As for the estimation of age among elderly people, the following methods were used. First of all, a family register was available for two-thirds of the subjects. If there was no register, the ages could be estimated by Chinese astrology or ages of their children who have family registers. Most Chinese acquire the habit of keeping records including information on their own Chinese astrology when they get married, and keep them until death. Information described herein is considered to be quite accurate. Age data in this study were based on the census in 1990. Table 1 shows age distribution of subjects. Sixteen Zhung Chinese, 2 Yao Chinese and one Han Chinese were found to be over eighty years of age.

\section{Dietary survey}

Twenty-two persons aged 80 to 107 were interviewed by a questionnaire concerning 24 hour dietary recall. Dishes served at an ordinary meal were also investigated. All information on dietary intakes was obtained through interpreters. When calculating nutrients of Chinese food, we used a Japanese food composition table, because we had no information on the composition of foods investigated in China. Data were described by using medians and ranges because of the small number of subjects.

\section{Collection and isotope analysis of hair}

Material used was 69 specimens of scalp hair of people in the autonomous country of 
Table 1. Age distribution of study subject

\begin{tabular}{|c|c|c|}
\hline Age & Male & Female \\
\hline & No. $(\%)$ & No. $(\%)$ \\
\hline $0-9$ & $6 \quad(37.5)$ & $8 \quad(15.1)$ \\
\hline $10-19$ & $3 \quad(18.7)$ & (18.9) \\
\hline $20-49$ & $2 \quad(12.5)$ & (15.1) \\
\hline $50-79$ & $2 \quad(12.5)$ & (18.9) \\
\hline $80-99$ & $2 \quad(12.5)$ & $10 \quad(18.9)$ \\
\hline $100-107$ & $1 \quad(6.3)$ & $7 \quad(13.1)$ \\
\hline Total & $16(100.0)$ & $53(100.0)$ \\
\hline
\end{tabular}

Bama, because we visited two Yao Chinese villages and two Zhung Chinese villages. The results of isotope analysis of these people are shown separately (Yao 1 and Yao 2, Zhung 1 and Zhung 2).

\section{Principle of isotope analysis}

Food is composed of chemical substances such as protein, carbohydrate and fat, which are essential for maintaining homeostasis in the human body. After absorption of these nutrients from the digestive system, they are used as materials that make up the human body and for energy. Particularly, protein (or amino acids) is largely used for the formation of tissue of the human body. This means that protein characteristics in food can be transferred to protein in the human body $[8]$. Therefore, we can estimate food intakes in daily life from the analysis of carbon and nitrogen isotopes composed of protein in the human body.

\section{Analysis}

First of all, both the hair and food of subjects in a study area were needed to analyze isotopes. Then isotope ratios of both carbon and nitrogen $\left(\right.$ ie, $\left.{ }^{13} \mathrm{C} /{ }^{12} \mathrm{C},{ }^{15} \mathrm{~N} /{ }^{14} \mathrm{~N}\right)$ were estimated. The following expressions were obtained between isotope of scalp hair and that of food $\delta{ }^{15} \mathrm{~N}$ (food $)=\delta{ }^{15} \mathrm{~N}$ (hair) $-4.3 \%, \delta{ }^{13} \mathrm{C}$ (food) $=\delta{ }^{13} \mathrm{C}$ (hair) $-2.5 \%$. A previous study on Japanese subjects showed that these expressions are similar irrespective of age or sex [8]. After adjustment for isotope ratios obtained from hair using these expressions, isotope ratios of food consumed can be estimated. In this study this expression was used, because we could not analyze isotopes of Chinese food.

A sample of about $1 \mathrm{mg}$ in weight was put into a container made of tin and then made gaseous using an element analysis machine(FISONS N1500). Generated carbon dioxide and nitrogen were transferred to GSR through interface (CONFLO $-\mathbb{I}$ ) to measure ${ }^{13} \mathrm{C} /{ }^{12} \mathrm{C}$ and ${ }^{15} \mathrm{~N} /{ }^{14} \mathrm{~N}$. Measured values were standardized by a standard gas and were shown in terms 
of delta per mil enrichment against an international standard article $\left(\mathrm{CO}_{2}\right.$ : Pee Dee Belmnite (PDA), N2 : nitrogen in the air) by the following expressions.

$$
\begin{aligned}
& \delta{ }^{13} \mathrm{C}=\frac{\left(\left({ }^{13} \mathrm{C} /{ }^{12} \mathrm{C}\right) \text { sample }-\left({ }^{13} \mathrm{C} /{ }^{12} \mathrm{C}\right) \text { PDA }\right)}{\left.\left({ }^{13} \mathrm{C} /{ }^{12} \mathrm{C}\right) \text { PDA }\right)} \times 1000(\text { per mil }) \\
& \delta{ }^{15} \mathrm{~N}=\frac{\left(\left({ }^{15} \mathrm{~N} /{ }^{14} \mathrm{~N}\right) \text { sample }-\left({ }^{15} \mathrm{~N} /{ }^{14} \mathrm{~N}\right) \mathrm{AirN}_{2}\right)}{\left.\left({ }^{15} \mathrm{~N} /{ }^{14} \mathrm{~N}\right) \text { AirN }{ }_{2}\right)} \times 1000(\text { per mil })
\end{aligned}
$$

The precision was within $\pm 0.2 \%$.

\section{Data analysis}

To examine the difference in $\delta{ }^{13} \mathrm{C}$ and $\delta{ }^{15} \mathrm{~N}$ between ethnic groups as well as age groups, Student's $t$ tests and Anova were used. Analyses were done with SAS (version 6.12).

\section{Results}

Regarding dishes at an ordinary meal, corn gruel was the chief staple diet of Yao Chinese and Han Chinese, but Zhung Chinese staple diet was rice. Dishes other than these staple foods were fried and boiled vegetables with soybean oil, water and salt. The menus for three meals each day were much the same and almost never changed throughout the year. Interviews regarding daily diet have shown that the food which children consumed daily was fundamentally the same as the food of other family members. According to 24 hour dietary recall, the energy intake ranged from 286 to $1152 \mathrm{kcal}$ (median $722 \mathrm{kcal}$ ). In regard to major nutrients, the median intakes (ranges) of protein, fat and carbohydrates were $16.1 \mathrm{~g}$ $(5.6-27.5 \mathrm{~g}), 7.9 \mathrm{~g}(1.6-26.5 \mathrm{~g})$ and $127.8 \mathrm{~g}(2.0-236.1 \mathrm{~g})$, respectively. No animal food was found among all subjects in 24 hour dietary recall.

Mean values of $\delta{ }^{15} \mathrm{~N}$ and $\delta{ }^{13} \mathrm{C}$ in the hair of Chinese people were 9.66 $\pm 0.65 \%$ (range: 8.41 to $11.15 \%$ ) and $-19.61 \pm 2.06 \%$ (range: -15.28 to $-22.52 \%$ ), respectively. In Fig. 2 , the upper axis and right axis are isotope values of hair, and the lower axis and left axis are isotopes of food estimated from isotopes of hair. Data on $\delta{ }^{13} \mathrm{C}$ in Yao Chinese and Han Chinese were scattered from -21 to $-17 \%$, which were close to isotope ratios of $\mathrm{C} 4$ plants such as corn and millet. On the other hand, data on $\delta{ }^{13} \mathrm{C}$ in Zhung Chinese were distributed from -25 to $-22 \%$, which were located near the isotope ratios of $\mathrm{C} 3$ plants such as rice, beans and potatoes. Values on $\delta{ }^{15} \mathrm{~N}$ in each group were distributed at the area ranged from 8 to $11 \%$. For Zhung Chinese, the distribution was separated, or equivalent ; data in Zhung 


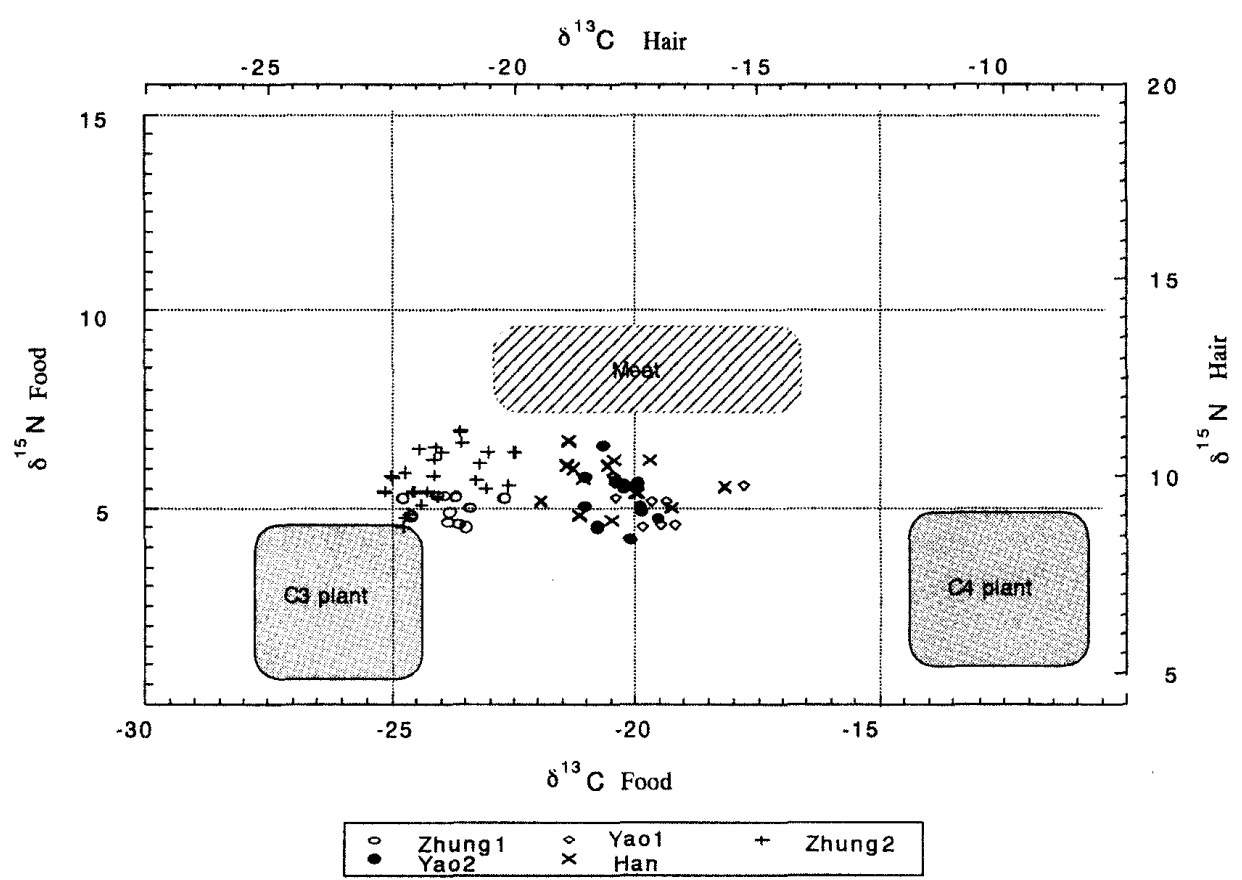

Fig. 2. Distribution of isotopes of hair by ethnic groups.

$\mathrm{C} 3$ plants area, $\mathrm{C} 4$ plants area and meat area mean the ranges of $\delta{ }^{13} \mathrm{C}$ and $\delta{ }^{15} \mathrm{~N}$ of $\mathrm{C} 3$ plants, $\mathrm{C} 4$ plants and meats, respectively.

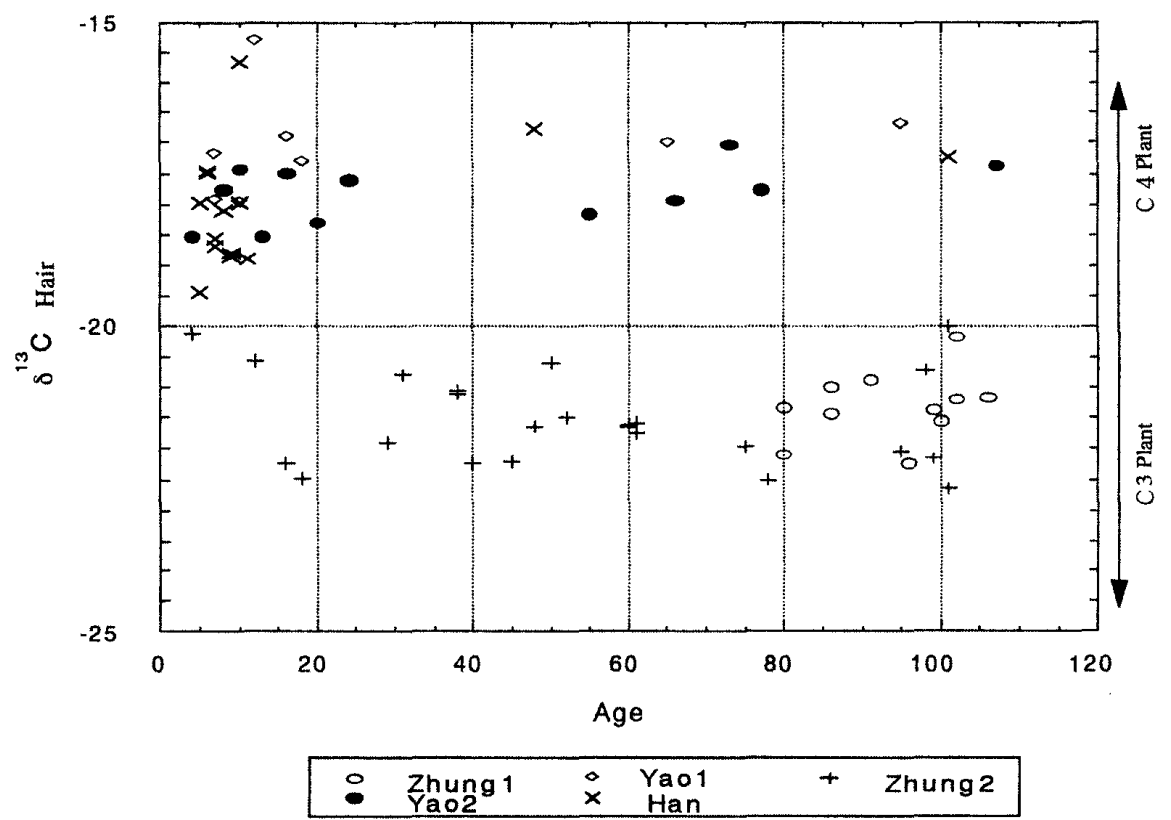

Fig. 3. Distribution of $\delta{ }^{13} \mathrm{C}$ by age.

1 were found to be about $9 \%$ and data in Zhung 2 were observed at about $11 \%$.

Figures 3 and 4 showed the distribution of $\delta{ }^{13} \mathrm{C}$ and $\delta{ }^{15} \mathrm{~N}$ by age and ethnic group. Distribution of $\delta{ }^{13} \mathrm{C}$ in Yao Chinese and Han Chinese was found to be below-20\%. In direct contrast, $\delta{ }^{13} \mathrm{C}$ in Zhung Chinese was distributed over $-20 \%$. There was a significant difference in mean values of $\delta{ }^{13} \mathrm{C}$ between Yao Chinese, Han Chinese and Zhung Chinese 


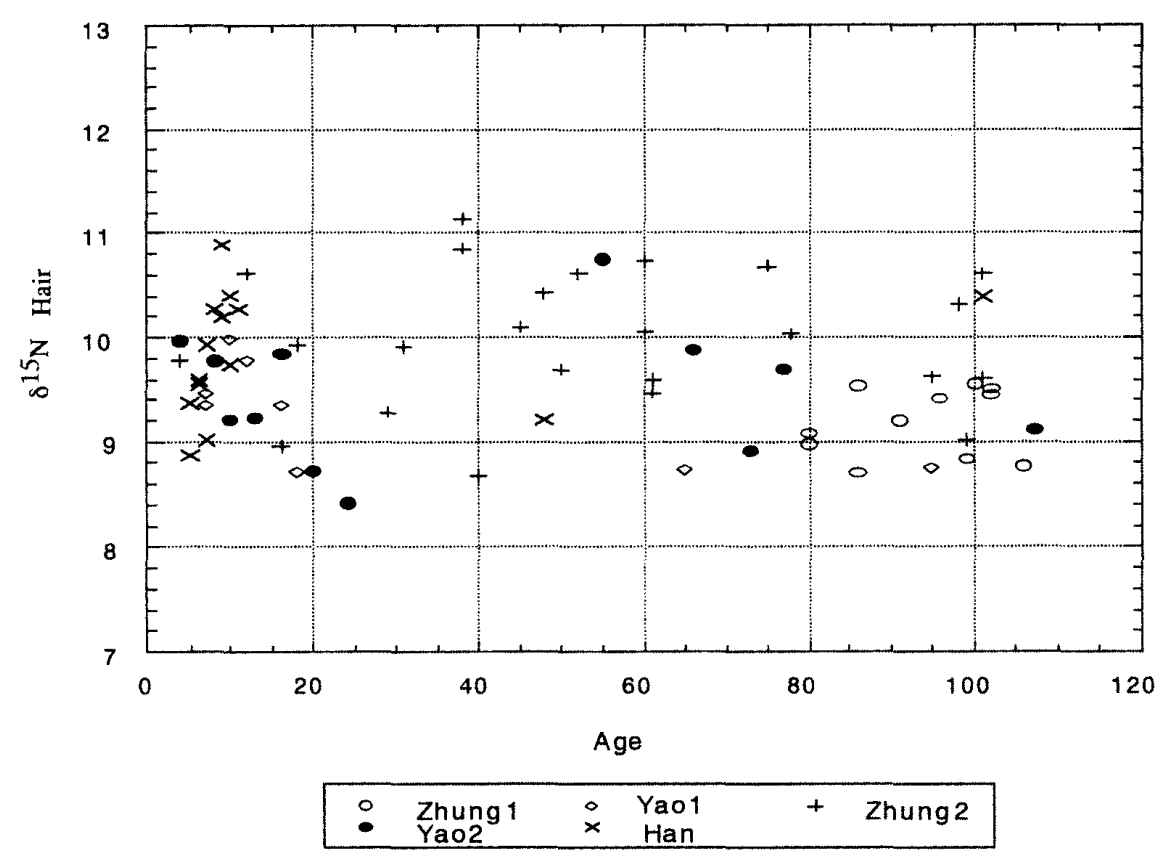

Fig. 4. Distribution of $\delta^{15} \mathrm{~N}$ by age.

$(\mathrm{p}<0.001)$. However, no significant association of $\delta{ }^{15} \mathrm{~N}$ with ethnic groups was found $(p=0.28)$. As to the results of the examination of the relationship between age and $\delta{ }^{13} \mathrm{C}$, $\delta{ }^{15} \mathrm{~N}$ by ethnic group, no differece between age was observed in $\delta{ }^{13} \mathrm{C}(\mathrm{p}=0.30$ : Yao and Han Chinese, $p=0.65:$ Zhung Chinese $)$, nor in $\delta{ }^{15} \mathrm{~N}(\mathrm{p}=0.42, \mathrm{p}=0.20)$.

We compared the distribution of study subjects with that reported in previous studies (Fig. 5 ), and found that the distribution of $\delta^{13} \mathrm{C}$ in our study subjects was widely spread compared with Chinese living in Beijing.

\section{Discussion}

$\delta{ }^{13} \mathrm{C}$ of human hair of children and elderly people in the autonomous country of Bama showed a much wider range than those of Chinese in Beijing and other ethnic groups reported previously. This distinguishing characteristic is due to the variety of dietary habits in the study subjects. There was a fundamental difference in the chief staple diet between Yao Chinese, Han Chinese and Zhung Chinese. The chief diet of the former ethnic group is corn gruel which is classified as a $\mathrm{C} 4$ plant. In the latter ethnic group, rice is the chief diet which is typical of a C3 plant. Therefore, the distribution of $\delta{ }^{13} \mathrm{C}$ of Yao Chinese and Han Chinese was on the left side of the $\mathrm{C} 4$ plant area and that of Zhung Chinese located near the $\mathrm{C} 3$ plant area. However, data on $\delta{ }^{15} \mathrm{~N}$ in study subjects were not in exact agreement with that of the $\mathrm{C} 3$ plant and $\mathrm{C} 4$ plant, because it was slightly higher. Probable causes are as follows. First, it is conceivable that isotope of plants produced in Bama could be slightly higher than similar Japanese plants. Second, our study subjects could consume animal 


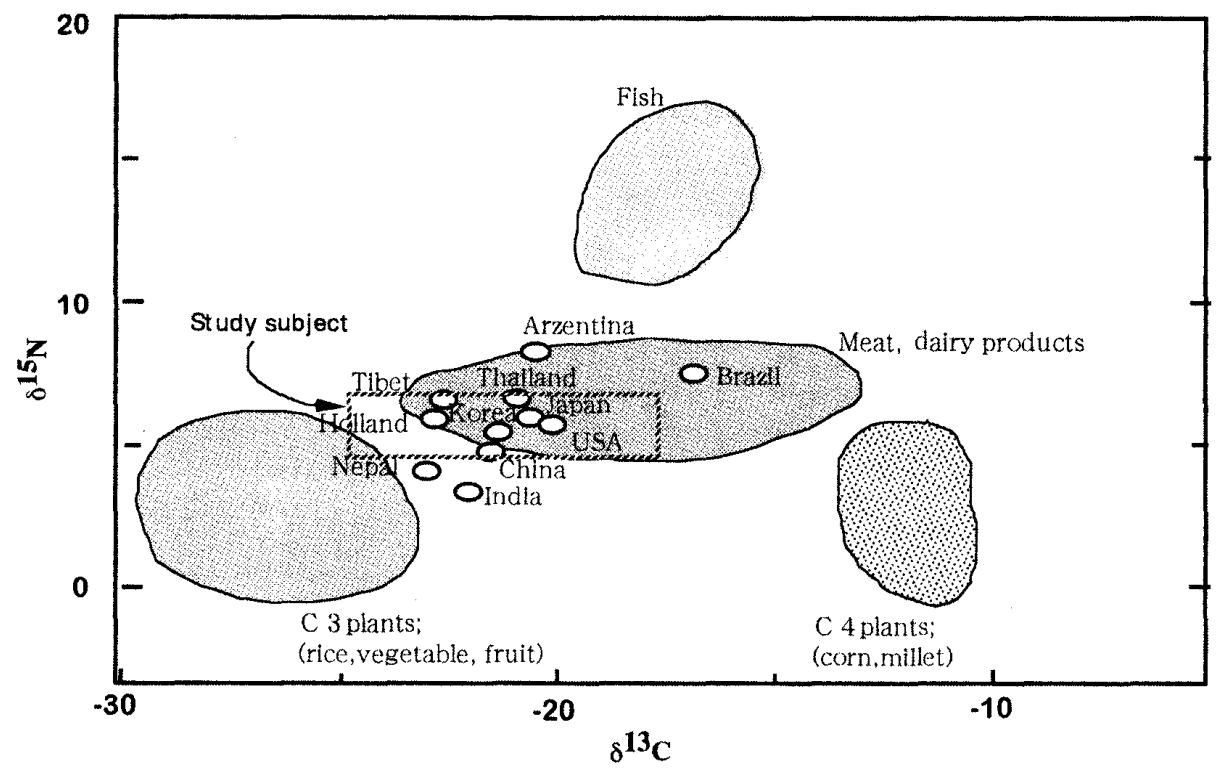

Fig. 5. Comparison of isotopes of ethnic groups with study subject. $\mathrm{C} 3$ plants, $\mathrm{C} 4$ plants, meat and fish areas mean the ranges of $\delta{ }^{13} \mathrm{C}$ and $\delta{ }^{15} \mathrm{~N}$ of $\mathrm{C} 3$ plants, $\mathrm{C} 4$ plants, meats and fishes, respectively.

foods despite no observation of animal foods in the dietary survey. The second factor could be responsible for this disagreement. There is a possibility that we could not obtain detailed information on dietary intakes from subjects because our interpreters were not experts in the dietary survey and most elderly people have difficulty in recalling dietary intakes.

In this study, we did not select subjects at random from the general population. There is no guarantee that data on isotope ratios obtained from our study subjects are representative of the population in this area. However, a dietary survey of a larger number of elderly people conducted by Dr. Chen (unpublished data) showed almost the same results as ours. In addition, foodstuffs are not in large circulation in this area due to the system of distributing commodities. These findings suggested that dietary intakes among study subjects could be representative samples of elderly people.

We used the expressions which were obtained using various kinds of Japanese food to investigate the relationship between isotopes of food and hair. The expressions should be essentially derived from data based on isotope analysis of Chinese foods. However, Minagawa showed that estimated isotope ratios of human hair using the expression derived from isotope analysis of Japanese food were almost equal to the observed ones of Koreans and Chinese people when isotope ratios were estimated [9]. This finding showed the validity of the expression used in this study.

Epidemiological studies have presented evidence that intake of animal foods increases the life span of humans. Shibata et al. investigated energy intakes among centenarians in 
Japan [10]. They found that the energy intake of these elderly persons was about 1000 $\mathrm{kcal}$, and that the ratio of protein intake to energy intake was $16 \%$, which was higher than the ratio of $14.6 \%$ at that time. Shibata concluded that diets among centenarians consisted of high proteins. In this study, we could not calculate exactly protein intake in daily life. However, the isotope analysis of the hair indicated that elderly people living in the area where many people have a long life span take less protein. This result differed from the above previous studies if dietary habits in Bama were related to longevity. Further study is needed to clarify whether dietary data obtained from the isotope analysis of the hair are related to longevity.

\section{Acknowledgments}

The authors thank all volunteers for providing hair samples, and Dr. J. Chen, President of Guangxi Longevity Research Center in the autonomous country of Bama in Guangxi and Mr. T. Kitaoka. This work was supported by the Egashira Foundation for the Promotion of the Hotel and Restaurant Industry.

\section{References}

1. Nakamura K, Schoeller DA, Winkler FJ \& Schmidth HL (1982): Geographical variations in the carbon isotope composition of the diet and hair in contemporary man. Biomed Mass Spec 9: 390394

2. Schoeller DA, Minagawa M, Slater R \& Kaplan IR (1986)：Stable isotopes of carbon, nitrogen and hydrogen in the contemporary North American human food web. Ecol Food Nutrition 18: 159170

3. Peterson BJ \& Fry B (1987) : Stable isotopes in ecosystem studies. Ann Rev Ecol Syst 181 : $293-320$

4. Hubner H (1986) : Isotope effects of nitrogen in the soil and biosphere. In: Handbook of Environmental Isotope Geochemistry (Fritz P \& Fontes JC, $e d$ ). Elsevier Science Pub. Amsterdam pp $361-426$

5. Minagawa M \& Wada E (1984) : Stepwise enrichments of ${ }^{15} \mathrm{~N}$ along food chains; further evidence and the relation between ${ }^{15} \mathrm{~N}$ and animal age. Geochim Cosmochim Acta $48: 1135-1140$

6. Rounick JS \& Winterbourn MJ (1986) : Stable carbon isotopes and carbon flow in ecosystems. Bio Sci 36: 171-177

7. Tieszen LL, Boutton TW, Tesdahl KG \& Slade NA (1983) : Fractionation and turnover of stable carbon isotopes in animal tissues: Implication for $\delta{ }^{13} \mathrm{C}$ analysis of diet. Oecologia $57: 32-37$

8. Minagawa M (1992) : Reconstruction of human diet from $\delta{ }^{13} \mathrm{C}$ and $\delta{ }^{15} \mathrm{~N}$ in contemporary Japanese hair: a stochastic method for estimating multi-source contribution by double isotopic tracers. Applied Geochemistry $7: 145-158$ 
9. Minagawa M, Karasawa K \& Kabaya Y (1986) : Carbon and nitrogen isotope abundances in human feeding ecosystem. Chikyu-Kagaku 20:79-88 (in Japanese)

10. Shibata H, Nagai H, Haga H, Yasumura S, Suzuki T \& Suyama Y (1992) : Nutrition for the Japanese elderly. Nutr Health $8: 165-175$

中国南部に居住する中国人における毛髪の炭素，窒素同位体分析を用いた食物摂取 評価

徳井 教孝 ${ }^{1}$ ，三成 由美 ${ }^{2}$ ，楠喜 久枝 ${ }^{2}$, 吉村 健清 ${ }^{1}$, 山元 寅男 ${ }^{3}$, 南川 雅男 ${ }^{4}$ 産業医科大学産業生態科学研究所 臨床疫学教室

${ }^{2}$ 中村学園大学短期大学部 食物栄養学科

${ }^{3}$ 中村学園大学

${ }^{4}$ 北海道大学大学院 地球環境科学研究科

要 旨： 長寿者の割合が多いと言われる中国巴馬県に扔いて, 3 つの民族(瑶族, 壮族, 漢族) 69名を対象に1998年, 栄養調查を行った。毛髮を用いて標準ガスで標準化された炭 素同位体比と窒素同位体比 $\left(\delta^{13} \mathrm{C}, \delta{ }^{15} \mathrm{~N}\right)$ を求め, 食物䀧取状況を評価した。瑶族と 漢族の $\delta{ }^{13} \mathrm{C}$ の分布は一 $21 \%$ 少らー17\%で，トウモロコシ，キビ，粟のような $\mathrm{C} 4$ 植 物の分布に近い值であった，壮族では一 $25 \%$ からー22\%に分布し，米，小麦，ジャ ガイモのような $\mathrm{C} 3$ 植物の分布に近かった。これらの值は都市在住の中国人に比べ, かなり広い分布を示した。一方， $\delta{ }^{15} \mathrm{~N}$ はどの対象者も $8 \%$ \%から $11 \%$ の範囲にみられ た. $\delta{ }^{13} \mathrm{C}$ の分布は食生活調查結果からも支持されるものであったが， $\delta^{15} \mathrm{~N}$ の分布は 予想より高い値を示した，毛髪の炭素，窒素の同位体比分析と長寿要因との関連は 明確でないが，3つの民族の同位体分析は特徵ある分布を示した。

J UOEH（産業医大誌）22（3）:219-228（2000） 